„Przekłady Literatur Słowiańskich”. T. 10, cz. 1

ISSN 2353-9763 (wersja elektroniczna)

DOI https://doi.org/10.31261/PLS.2020.10.01.01

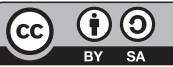

\title{
Translation as a Poetics Constituent ${ }^{*}$
}

\section{Przekład jako składnik poetyki}

\author{
Cvijeta Pavlović
}

iD https://orcid.org/0000-0002-5800-961X

UNIVERSITY OF ZAGREB

cvijeta.pavlovic@ffzg.hr

Date of application: 15.09.2019 | Date of acceptance: 10.02.2020

\begin{abstract}
August Šenoa (1838-1881) is a central figure of the Croatian literature of the second half of the 19th century. He consistently implemented the ideas from his theoretical treatises in his literary opus and formulated his poetics of translation in accordance with his literary ideas. In that system Romance and Slavic literatures were thus given a special place, and on the stylistic-historical level, Šenoa advocated for the transitional period from Romanticism into Realism. The examples of Šenoa's translations of world literature into the Croatian language and the most recent translation of Šenoa into English reveal that in the adaptations the periphery and the centre, in the changeable relations of the economy of literature, draw near each other.
\end{abstract}

KEYWORDS | translation, August Šenoa, periphery, romanticism, realism

* This article was financed by the Croatian Science Foundation through the project European Foundations of Croatian Literature (HRZZ IP-2016-06-2613). I conducted research in the archives of the Division for the History of the Croatian Theater, Institute for the History of Croatian Literature, Theater and Music at the Croatian Academy of Sciences and Arts. 
Literary translations of August Šenoa, one of the most important Croatian writers and translators of the 19th century, will be analysed in this paper in the context of the periphery in language, literature and culture. But firstly, it is important to note that many analyses focus primarily on the social and political nature of literary translation; philosophical nature is also often included, even if only implicitly. However, the aesthetic nature of literary translation is evidently perceived as "too difficult" or "too complex" for average readers and too complex to comprehend in modern times - and therefore often avoided. This is exactly the reason to dedicate a comparative analysis to this subject.

For both the translation studies and comparative studies, the periphery represents a valuable place for research on the map of world literature. Analyses of translations of central literatures into periphery consider how these central literatures function in translation to peripheral languages, literatures and cultures, they consider the role these translations perform and even their place in periphery. With regard to Croatian literature, the chosen central languages are French, German, English and Italian. Another interesting issue is connected to the ways in which peripheral literatures translate each other in the context of South Slavic and West Slavic languages, literatures and cultures. One can ask, for example, whether Polish language is peripheral or perhaps central for the 19th-century Croatian culture and literature, or whether that central role belongs to Czech or Slovakian languages, or perhaps Russian, and so on.

Moreover, it is important to bear in mind that the 19th century is relevant as an era of the standardisation of many Slavic languages and their transformation into modern categories of communities - languages - nations.

In the Croatian history of literature, August Šenoa is comprehended through the poetics of Romanticism. As a consequence of the 19th century national movements, the aesthetic category of Realism has been on the margin or in the periphery of comparative studies and translation studies for too long. It is now time to consider aesthetic and poetic consequences, causes and effects of the selected translations regarding:

1. Peripheral authors and genres of translated literature.

2. The peripheralisation of an author or translator, source culture or target culture.

3. The place of translations from peripheral literatures in a network of translation from other languages.

4. The peripherality of languages and literatures, both source and target, compared to literatures and languages with a wider range.

But most important to the subject is the following:

5. The fact that translations occupy the periphery or the margin in the writers' scope in the sense this scope is understood in literary history. 
They are considered as classics significant of an era, they are considered through their fiction, through their culture or political meaning, etc. But the times are ripe to admit that there are many significant and important bonds between the author's poetics and his choice of literary translation in translation work.

In the introduction, I have presented central propositions which I will follow and elaborate in the main part of my paper. Now I continue by briefly situating Croatian literature of the second half of the 19th century in the European context.

August Šenoa figures as the central Croatian personage in the culture of the second half of the 19th century, and a whole period — from 1865 (or, according to other criteria, from 1871) until Šenoa's death in 1881 - is called Šenoa’s Age. Such nomenclature is of course comparable to the period names on European and global planes (for example, Goethezeit), and sometimes represents the most useful solution for the stylistic-historical tangles that occasionally appear when attempting a periodisation of literature. Indeed, the stylistic-historical periodisation of the second half of the 19th century contains several still unresolved knots that point to the unpreparedness of scholars to coordinate names and definitions, both in Croatian as well as in European literature. Šenoa's Age is frequently erroneously read through the optics of Romanticism even though Šenoa was fully aware that he belonged to the generation, period and poetics different from the representatives of the Croatian National Movement and Illyrism which were informed precisely by the Romantic taste. On the other hand, Šenoa really did use segments of Romanticism and even older Sentimentalism, which is not an extraordinary occurrence among the European writers of the 19th century. In that sense Šenoa could perhaps be described as a representative of the Croatian literature of late Romanticism. However, a significant portion of Šenoa's opus is structured on the concept of Realism, including not only novels and novellas concerning contemporary life, but also all of his contribution to Croatian drama. Croatian literary historians often wrote their texts while in awe, that is, feeling inferior in relation to "major" European literatures, which consequently but erroneously leads to the transmission and perpetuation of the idea and the name Proto-Realism. This term was used by Miroslav Šicel ${ }^{1}$ and Ivo Frangeš, ${ }^{2}$ and justifiably so in their times, since they wanted to introduce into the history of Croatian literature - and it had to be conceived within the framework of Yugoslav literatures - the possibility of a period which differed from

1 M. Šicel, 1966: Pregled novije hrvatske književnosti. Zagreb, Matica hrvatska; M. Šicel, 1997: Hrvatska književnost 19. i 20. stoljeća. Zagreb, Školska knjiga.

2 I. Frangeš, 1987: Povijest hrvatske književnosti. Zagreb-Ljubljana, Nakladni zavod Matice hrvatske i and Cankarjeva založba. 
Romanticism as well as from Modernism, a period where literature tended to serve as "a mirror to life" and a portrayal of social structure. This tendency, according to the criteria of the day, the perceptions of stylistic-historical formations and the complex of peripheral receptive literature, remained in its infancy and therefore carried the prefix "proto" because it did not reach the level of H. Balzac, G. Flaubert, Ch. Dickens, N. V. Gogol, F. M. Dostoyevsky, L. N. Tolstoy and others. Even though Frangeš initially wrote about Realism, ${ }^{3}$ in his monograph he entitled a chapter "Proto-Realism. Realism" which he dedicated to the second half of the 19th century with echoes into the 20th, and where he included a range of authors from August Šenoa, Dragojla Jarnević and Janko Jurković to Silvije Strahimir Kranjčević, Ksaver Šandor Gjalski, Fran Mažuranić and Viktor Car Emin. ${ }^{4}$ Frangeš inherited such a periodisational compromise from earlier literary historians ${ }^{5}$ so the term Proto-Realism becomes a variation on the theme that has only recently, from the 1990s, been given its clearer contours. Krešimir Nemec also discussed the periodisational problems (in conjunction with the inclusive programme of the 19th century Croatian literature as educational medium): while dealing with the topic of the most important genre of Realism - the Croatian novel, Nemec creates a special section entitled "The Problem of Realism in Croatian Literature," within the larger chapter "The Golden Age of the Croatian Novel"; however, while respecting the periodisation as was defined by earlier histories of Croatian literature, Nemec writes of "folklore realists," "followers of the Croatian Party of Rights and Realism," and other. ${ }^{6}$ On the other hand, Slobodan Prosperov Novak, ${ }^{7}$ even

3 M. Živančević, I. Frangeš, 1975: Povijest hrvatske književnosti. T. 4: Ilirizam. Realizam. Zagreb, Liber-Mladost.

4 I. Frangeš, 1987: Povijest hrvatske književnosti. Zagreb-Ljubljana, Nakladni zavod Matice hrvatske and Cankarjeva založba.

5 For example, D. Prohaska, 1919: Pregled književnosti hrvatske i srpske I. (Do realizma 1880). Zagreb, Vlastita naklada, Kraljevska zemaljska tiskara (reprinted as: Hrvatska čitanka za 3. i 4. raz., Zagreb, Trgov. akademija, 1918), etc. Already Prohaska situates "the real" Realism (too) late (at a time when in Croatian literature there are already discernible modernist tendencies, which was proven by newer literary historians). On the other hand, for example, Mate Ujević decides for synthetic terminology. M. Ujević, 1932: Hrvatska književnost. Pregled hrvatskih pisaca i knjiga. Zagreb, Hrvatsko književno društvo sv. Jeronima. In his history of Croatian Literature, Ujević, for example, uses "between Romanticism and Realism" as a syntagm for Šenoa, while he describes Eugen Kumičić, Ante Kovačić and others as "Realist writers," and goes on to identify "Realist-Romantic" writers and essayists in those times.

6 K. Nemec, 1994: Povijest hrvatskoga romana. Zagreb, Znanje.

7 R. Katičić, S. P. Novak, 1987: Dva tisućljeća pismene kulture na tlu Hrvatske. Zagreb, SNL; S. P. Novak, 2003: Povijest hrvatske književnosti. Od Bašćanske ploče do danas. Zagreb, Golden marketing. 
though he does not decide on a periodisational structure, interprets Realism in Croatian literature, while Dubravko Jelčić, with his idea of the beginnings on the one hand and of the "weariness" of the period or a mannerism of sorts on the other, comes close to the European tendencies of complicating period boundaries. Jelčić consequently writes of "late Romanticism, early Pre-Realism," then of "Šenoa’s Age" and finally of the "Croatian Literary Realism." Vinko Brešić primarily studies 19th century literature through the optics of the genres and even using that criterion he recognises Realist in Croatian literature.

Histories of Croatian Literature are gradually coming to recognize in August Šenoa's literary style the traits of the transitional period in which he greatly contributed to the inauguration of realist poetics. A comparative reading of the socalled minor European literatures confirms that peripheral European literatures do possess their Realisms, but also a common European realist poetics - shared to the same extent in which this can be said of, for example, Baroque and even Romanticism. Moreover, Polish literature rightfully prides itself on the period of the so-called Positivism, while Croatian literary history was for a long time too timid. Judging by the numerous projects and conferences appearing lately, it seems that a pan-European revision of Realism as a significant direction in $\operatorname{art}^{10}$ is underway, and that the emphasis is put on the European periphery which quantitatively dominates over the so-called qualitatively great Realisms of French, English and Russian literatures, so that the periphery is now re-centred in order to redefine stylistic-historical edges and boundaries.

Corpora of translations of authors who greatly marked the age of national literature can be of help in the establishment of stylistic-historical signs. The next step is, therefore, to study the relationship between Šenoa's fiction and his opus of translations.

Šenoa matched his poetics of translation to his literary views formulated in his treatises, especially in his earlier programmatic texts Naša književnost

8 D. Jelčić, 1997: Povijest hrvatske književnosti. Tisućljeće od Bašćanske ploče do postmoderne. Zagreb, P.I.P. Naklada Pavičić.

9 V. Brešić, 2015: Hrvatska književnost 19. stoljeća. Zagreb, Alfa.

10 K. Hanshew, 2018: Comparing Canons: Croatian and German Realism - A Proposal. In: C. Pavlović et al., eds.: Komparativna povijest hrvatske književnosti, t. XX. Književni kanon. Split-Zagreb, Književni krug (Literary Circle) - Department of Comparative Literature, the Faculty of Humanities and Social Sciences, University of Zagreb, pp. 92-100; research undertaken within the international project Economic Foundations of Croatian Literature (HRZZ IP-2016-06-2613, project leader Dr. Maša Kolanović, University of Zagreb); a possible European project on Realism in European literatures Landscapes of Realism. For this information I thank Prof. Jelena Šesnić (project leader: Prof. Dirk Göttsche, Nottingham University; collaborators Prof. Svend Erik Larsen et al.), and others. 
(Our Literature) from 1865 and O hrvatskom kazalištu (On Croatian Theatre) from 1866. Such coordination of translation and fiction implies a system in the selection of works for translation into the Croatian language, the more so when one takes into account that the Croatian readership of Šenoa's times read without difficulty, or even primarily opted for, works in German or Italian language (depending its situation on the Croatian North or South). In this system Šnoa awarded a special place to Romance and Slavic literatures with the help of which he continuously opposed, at least in intent, the German influence: he did not reject German classics (J. W. Goethe, F. Schiller, and generationally closer $\mathrm{H}$. Heine), but rather aimed to stop the flood of second- and third-rate German and Austrian literary attempts at fast and easy money which were spreading in the provinces and the periphery of the Austro-Hungarian Empire. Polish literature played an important role in his system, and Šenoa translated a fragment of Mickiewicz's Konrad Wallenrod ("Pozor" 1862), a historical ballad Jan Bielecki by Juliusz Słowacki ("Vienac" 1879) and Antoni Gorecki's patriotic poem The Death of the Traitor of the Nation ("Vienac" 1879; Śmierć zdrajcy ojczyzny).

Translations from Slavic literatures also carried over Romanticist poetics dominant in their source countries so Šenoa as a translator from Slavic languages basically transferred these contemporary stylistic formations as well, that is, he brought over current literary interests. Mickiewicz, Gorecki and Słowacki are the representatives of Romanticism which is, comparatively speaking, similar to early Croatian Romanticism in the political period of the National Movement. On the whole, and taking into account Šenoa’s overall work in translation, his selection of authors for translation - instead of his contemporaries - logically included a larger number of writers several decades older than him, representatives of the European and world Romanticism. Indeed, in Polish literature Positivism had by that time not yet emerged. However, even within Šenoa's selection of European Romanticists one can discern the importance of the social dimension which will, together with the national and historical dimension, continue to attract Šenoa to the same extent both in his translations as in his authorship. Thus, for example, Šenoa translated Heine's satirical poem Solidität - Čist račun ("Naše gore list" 1865; along with Alte Rose - Stara ruža, whose satire is thematically different), Thomas Hood's The Song of the Shirt - Pjesma o košulji ("Vienac" 1872), Longfellow's The Old Clock on the Stairs - Stara ura and The Slave's Dream - San roba ("Vienac" 1874) while in his legacy he left the translation of Longfellow's The Spirit of Poetry - Duh pjesništva. ${ }^{11}$ Heinrich Heine (1797-1856), the contemporary of eminent Polish Romanticists, in the

11 A. Šenoa, 1963: Sabrana djela. Pjesme. T. 1. S. Ježić, ed. Zagreb, Znanje. 
context of 19th-century German (and French) literature represents the formation of late Romanticism on the eve of Realism; Thomas Hood (1799-1845) is in English literature close to realist temperament, especially when in simple images he describes the conditions of everyday life, and in his Song of the Shirt (1843) he reached European popularity and inspired social activists. He was a friend of W. M. Thackeray, he was valued by Charles Dickens, and he was translated into German by Ferdinand Freiligrath (1810-1876). Somewhat younger American poet Henry Longfellow (1807-1882), the contemporary of Słowacki and Šenoa, continues the Romanticist tradition, but the poems that Šnoa chose for translation are similar to Šenoa's own thematic concerns of Romanticist-Realist provenance, especially in the linking of the idea of transitoriness, fate and social topics with the idea of freedom.

Šenoa's translations are in general closer to adaptations with interesting relationships between adequacy and ethos, and primarily in the range of nuances of etymology of adequacy and equivalence, that is, of the adjectives aequus and adaequus. On these and other terms Croatian translation scholar and translator Iva Grgić Maroević published relevant books ${ }^{12}$ which greatly supplement frequently referenced sources in the translation theory, often constructed only on the experience of translating from the English language. For Croatian translation theory the most important work is the introductory handbook on translation theory with the English backdrop entitled Introduction to Translation Theories by Nataša Pavlović. ${ }^{13}$

In the context of adaptation as transfer of culture Šenoa's corpus of dramatic texts translated from French is significant, ${ }^{14}$ and among them the most interesting are texts by Eugène Scribe (1791-1861), Delphine de Girardin (18041855), Baron Anne-Honoré-Joseph Duveyrier Mélesville (1787-1865) and Honoré-Marie-Joseph Duveyrier also called Mélesville the Son (1820-1904), Eugène Labiche (1815-1888) and Victorien Sardou (1831-1908) who was generationally closest to Šenoa. Even though most of the French plays translated by Šenoa were written in the epoch and poetics of Romanticism, they belong to the genre pièce bien faite (well-made play), a bourgeois comedy which paves the way for Realism (including drama, melodrama, comedy and vaudeville).

Šenoa's translations of these plays are still in their manuscript form, so in my analysis I used archival materials of the Croatian Academy of Sciences and Arts, and this paper is the continuation of the research conducted some fifteen

12 I. Grgić Maroević, 2009: Poetike prevođenja. O hrvatskim prijevodima talijanske poezije. Zagreb, Hrvatska sveučilišna naklada; I. Grgić Maroević, 2017: Politike prevođenja...

13 N. Pavlović, 2015: Uvod u teorije prevođenja. Zagreb, Leykam international.

14 C. Pavlović, 2006: Šenoina poetika prevođenja. Traduktološka analiza Šenoinih prijevoda s francuskoga jezika. Zagreb, Matica hrvatska. 
years ago. ${ }^{15}$ Considering the new media, the Internet and the online availability of the original texts, it is finally possible to compare the archival materials that were previously only bibliographically noted but not available in full text online and furthermore unavailable for inter-library loan on the relation Paris-Zagreb in the 1990s, when the research was initiated. However, by going through the materials in the possession of the Division for the History of the Croatian Theater, it became clear that during the transfer, in the olden days, of the manuscripts from the Croatian National (Land) Theatre to the Institute for the History of Croatian Literature, Theater and Music of the Croatian Academy of Sciences and Arts, one manuscript from Šenoa's corpus of dramatic texts was lost, and it was unfortunately the manuscript of the play by Scribe, Villeneuve and Desvergers Yelva, or The Russian Orphan - Jelva ili ruska sirota (Yelva, ou L'Orpheline russe) which was very popular in the German-speaking territories and that is probably how Šenoa heard of it. In the second act of the play the plot takes place in the then Polish-Russian estate several miles from Vilnius (today the capital of Lithuania), the property belonging to the Russian nobleman Tcherikof, ${ }^{16}$ and it would be interesting to analyse how Šenoa transferred the Polish-Russian setup, how much he kept and how much he adapted, simplified or amplified. The more so since it has already been established that Šenoa readily adopted particular cultural and political standpoints, both in his translations as well as in his authored texts so, for example, in several well-known historical short stories he openly, in various historical clashes, took the side of Poland and the Polish people, particularly in the Polish-Russian wars, and he was against the idea of pan-Slavism which contained the trap of imperialism. ${ }^{17}$

As an example I will closely analyse Our Good Villagers - Dobričine seljaci (Nos Bons Villageois, 1866) by Victorien Sardou, whose comedies were successfully staged since 1854, that is, in the period when Šenoa was establishing himself as a cultural worker and writer. It is interesting to investigate in what ways Šenoa's and the Croatian "periphery" understand and translate the text of a French contemporary at a time when French literature is dominated by Realism (inaugurating the period of Naturalism), while Croatian literature is

15 C. Pavlović, 2006: Šenoina poetika prevođenja...

16 In the original the stage directions state: "[...] dans la Pologne-Russe, à quelque lieues de Wilna. [...] Seconde partie: Le théâtre représente une grande Salle d'un château gothique: porte au fond; à droite et à gauche, une grande croisée; sur le premier plan, deux portes latérales. Lappartement est décoré de grands portraits de famille," etc. E. Scribe, T. Villeneuve, Desvergers, 1844: Yelva, ou Lorpheline russe. Bielefeld, Velhagen \& Klasing. Online-Ausgabe: Karlsruhe: Badische Landesbibliothek. Yelva [online] https://digital.blb-karlsruhe.de/urn/urn:nbn:de:bsz:31-90123 [25.10.2018].

17 C. Pavlović, 2005: Priča u pjesmi. Pripovjedni postupci Šenoine epske poezije. Zagreb, Disput. 
undergoing the shift from Romanticism into Realism. The translation is interesting for two strong emphases that are made in it:

1. The focus is placed on the peasant class.

2. It confirms the translator's inclination to satire which was characteristic both for Sardou's and Šenoa's path towards Realism.

According to certain traditional classifications Sardou is tied into the context of Naturalism, where the term is used in such a way to include traits of both Realism and Naturalism. ${ }^{18}$ Naturalism is here of course conceived as a literary movement which broadens its interest in the class issue from the middle bourgeois class to the lower classes which then in many ways and through different plots return and from a larger perspective influence the middle and upper classes. However, Sardou is frequently described only as a skilful vaudeville writer, a caricaturist, a technician and a master of special effects, artificial and insincere writer who, nonetheless, best knows how to fill a theatre. Compared to him, Émile Augier and Alexandre Dumas the son are artistically better appreciated, but Sardou is acknowledged for his masterful dialogues and comebacks, and especially the turn toward the social satire. ${ }^{19}$

Sardou's good fit with the realist tastes of the Croatian audiences is confirmed by a line of performances in the 1870s, 1880s and 1890s in Zagreb and Karlovac. ${ }^{20}$ Thus Šenoa with this translation of the play actively contributed to having Croatian audiences follow current events in European literature and to offering them a relevant topic in a popular format.

Šenoa's adaptation of the French text for Croatian audiences on the example of Our Good Villagers can be summarized to the following techniques:

18 G. Lanson, 1966: Histoire de la littérature française. Remaniée et complétée par P. Tuffrau. Paris, Librairie Hachette, pp. 1029, 1072. According to this, today outdated classification, Naturalism is a period of French literature dating from 1850-1890. Even though this classification was criticised and consequently abandoned, in the context of world literature and especially regarding the dictates of the poetics of Realism, it takes into account that in the second half of the 19th century, there prevailed the scientific spirit (esprit scientifique) and industrial development, which were reflected on the new poetics that would impose itself in the late 1860s. In new theories of culture such criteria are once again gaining importance in the question of periodisation and classification of literature and art.

19 G. Lanson, 1966: Histoire de la littérature française... , p. 1072; G. Ducrey, ed., 2007: Victorien Sardou, un siècle plus tard. Strasbourg, Presses universitaires de Strasbourg; I. Moindrot, ed., 2011: Victorien Sardou, le théâtre et les arts. Rennes, Presses universitaires de Rennes (PUR).

20 G. Lanson, 1966: Histoire de la littérature française..., p. 1072; G. Ducrey, ed., 2007: Victorien Sardou, un siècle plus tard. Strasbourg, Presses universitaires de Strasbourg; I. Moindrot, ed., 2011: Victorien Sardou, le théâtre et les arts. Rennes, Presses universitaires de Rennes (PUR). 
1. Addition - for example, exclamations and appellatives and metaphors in the spirit of the language:

Il faut bien rire un peu, pas vrai!... Vous devez aimer à rire, vous? Je vois, ça! Smij se (samo), ${ }^{21}$ djevojko, smij. - Čini se, da se rado smiješ. —Znam ja vas mlade jarebice. (I, 4)

In the original, there is no metaphor for girls as "mlade jarebice." Il faut taller coucher... - počini $\underline{\text { dušo! }}(\mathrm{V}, 4)$

In the original, there is no appellative "dušo."

2. Omission

prenant son chapeau pour sortir - uzme ššir $(\mathrm{V}, 4)$

It is understood that he takes a hat in his hand in order to exit so the "pour sortir" is not translated.

ce petit rousseau là-bas, qu’a un gilet jaune... - Eno onaj sa žutim prslukom! $(\mathrm{V}, 4)$

"[T]hat young red-head" is missing.

Short replies, reactions, insertions are missing - one dramatic person is telling the whole semantic unit.

1. Adequacy

et my retirer en manches de chemise!

i da mogu hodati bez kaputa (I, 4)

2. Arbitrary change

une dent - njekoliko zubi (V, 4)

3. Adaptation

- cultural-lexical level

le pistolet - samokres, kubura, ali i pištolj i sl.

... une partie au Cirque de Gavarnie - u goru (V, 4)

- phraseological level

Vous voyez un homme, jeune fille, qui réalise le rêve de toute sa vie.

Eto ti mene, čovjeka, koji je doželio zlatne sanke života svoga.

21 The brackets contain interventions, that is, later added in pencil in Šenoa’s manuscript. One part of those interventions, it is possible to assume, were written down by Šenoa 
In the original, it says "dream" (le rêve), while in the translation it is "zlatni sanci." (I, 4)

Jamais de la vie... - sačuvaj Bože $(\mathrm{V}, 4)$

...(entre nous, n'est-pas?) Parce que je crois que Pauline ne l'aime pas beaucoup - ... Ler da ti po duši kažem - jer ga živa gledati ne može (V, 4)

Mais, au moins, écrivons-lui, prévenons-le... Cést inutile... - mi odosmo nerekav jadnom Henriu ni slovca.

"Ni slovca" is adaptation and also shortening of the statement "pišimo mu"... "beskorisno je" (écrivons-lui"... "cest inutile").

cher ange - dušo $(\mathrm{V}, 4)$

Mon amie!... mon enfant! — Ženo! Dušo! (V, 4)

End of the play: the Baron asks Morisson: Alors, vous retournez à Pariz? Vi ćete natrag u Pariz? and receives Morisson's reply: Ah!... Je me le demande si jy retourne! - I kruto! (I te kako!) ${ }^{23} \mathrm{Na}$ četiri konja! (V, 6)

These techniques result in a translation in which Sardou's well recognizable fast and fragmented conversation is made more moderate and calm. There are no repetitions or variations in the translation. However, in relation to the dominant drama of the time, this text represents a refreshing innovation for Croatian theatre audiences that are being introduced to a faster dialogic exchange between characters and faster shifts between scenes and situations.

Šenoa followed literary fashions in European cultural centres among which France held a prominent position. His criteria for the selection of texts were not based exclusively on the stylistic-historical periods, but the list of Šenoa's translations shows that he always tried to offer the most current literary texts, among which was Sardou's realist comedy. Cultural centres were also financial centres so the social-economic capital stimulated interest in cultural capital, ${ }^{24}$ which was in turn filtered by the cultural-political orientations within European literatures, where Šenoa made the political decision to prioritise French literature and culture over then cultural and political oppressive German-Hungarian complex. From the perspective of periphery, the choice of the centre is not

himself, while the other part must have been created in later adaptations of the text for the stage, whether by the director or some other theatre person.

22 In the manuscript "ni slovca" is crossed out; instead "sbogom" is pencilled in.

23 In the manuscript "I kruto!" is crossed out and "I te kako!" is written instead.

24 P. Bourdieu, 1998: Les Règles de l’art: genèse et structure du champ littéraire. Paris, Édition du Seuil. 
entirely free, rather, it is conditioned; however, a possibility of choice exists in the economic-cultural conjunction of the leading countries and cultures.

When the aspect of tourism is observed within economy, Croatian peripheral areas become transformed into one of the centres of European tourism, especially at the beginning of the 21st century. In that context one needs to take into account the shift that is occurring in our times. Šenoa has been translated into many world languages, but only the newest English translation of Šenoa's first historical novel Zlatarovo zlato (The Goldsmith's Treasure) (1871) produced the desired reaction of European proportions.

In imagology Croatia is a land for summer holidays, a tourist destination, and tourists like to read works from the country where they visit. Despite the existing translations to German, Polish, Czech, Slovak, Russian, Italian and other languages, today tourists react mostly to the books translated into English and it consequently occurs that even tourists from non-English speaking countries opt for the English translation of The Goldsmith's Treasure $(2015)^{25}$ as a confirmation of availability and a certain global value, and then potentially quality as well. The Goldsmith's Treasure has become a bestseller both for tourists and Croatian audiences. ${ }^{26}$

Adaptation for tourist purposes was necessary and it seems it has never bothered anyone, just as similar interventions in Šenoa's solutions did not bother the audiences of Šenoa's Age. The book was bought: (1) in order to have it on the library shelves as a representative piece of Croatian culture, and for decorative purposes because of its golden binding, (2) as a gift for friends abroad or for Christmas, as witnessed by the booksellers. Taking into account all of these indicators, and taking into account the final reader of the product, the English edition adapted, in the spirit of tourism the very ending of the novel.

Ruši se stara gradina, ruši, nu dalje, dolje pod gorom uspinje se sjajan, snažan kao mlađahan junak - naš Zagreb grad.

But the old fort lies in ruins, crumbling into dust. Yet below the mountain, a jewel most precious to us glimmers in the sun, strong like a mighty hero... the town of Zagreb.

Our town Zagreb, as it is written in the original, became in the English translation the town of Zagreb, losing its possessive pronoun "our" and receiving a more general "tourist" or universal meaning as a message of a town that is beautiful, historically interesting, but lacking the marker of intimacy.

25 A. Šenoa, 2015: The Goldsmith's Treasure. N. Divjakinja, trans. Zagreb, Spiritoso.

26 A. Šenoa, 2018: The Goldsmith's Treasure (2nd ed.) N. Divjakinja, trans. Zagreb, Spiritoso. 
The selected title from Šenoa's opus for translation into English came from the genre of the historical novel, more precisely it is the title that marks Šenoa as the founder of the Croatian novelistic Romanticism. However, in the case of this translation Romanticism is not important as a representative; relevant here instead is the genre of the historical novel independently of the stylistic-historical period characterised by it. Šenoa's realist novels and short stories do not aim to portray space (topos) and history (in the sense of history historia but also time kronos) in the way in which these are depicted by historical novels, whereas in the promotion of a city and, more broadly, a culture the most efficient mode of representation is precisely the historical novel which as a genre successfully survives stylistic-historical changes. Therefore, the translation of The Goldsmith's Treasure to English in the current cultural capital does not only represent the marker of Romanticism, but it also features the following: the marker of Romanticism overshadowed by the primary message of the novel as a marker of the chronotope that is understandable to a broader circle of readers, as well as the literary representative of the chronotope that can be reconstructed in situ, and is at the same time dedicated to the capital of Croatia in a way in which in France, for example, Victor Hugo's novel Notre Dame de Paris does for Paris.

Thus, to use Bourdieu's ${ }^{27}$ terms, it can be shown that the cultural capital of translation stands in a close relationship to political and economic capital which today carries with itself English language as lingua franca. This translation represents Šenoa as a Romanticist to the world, but this one work (or one genre, in this case of the historical novel) does not make him so, and finally, the stylistic-historical affiliation ceases to be the decisive representative.

In this context, in Croatian literary theory and criticism it was already Miroslav Beker who noticed, while commenting on the works of Itamar Even-Zohar, that peripheral literatures frequently adopt the traits of the generally accepted repertoires (e.g., Realism, Romanticism, Symbolism) and this does not occur necessarily through the major writers; instead, the role models are usually relatively minor authors who developed simpler models for adoption. Any adopted element can, due to forces at home, obtain a different function in the receptive literature. $^{28}$

In the 19th century the language of Europe and the Western Circle was not English, but the relationships were similar, peripheries measured each other up and were brought closer through translations. The translation of Šenoa's novel to English is a certain adaptation to the extent to which Šenoa himself translated,

27 P. Bourdieu, 1998: Les Règles de l'art...

28 M. Beker, 2001: Teorija o dinamičnom funkcionalizmu Itamara Even-Zohara. „Umjetnost riječi", no. 1, p. 11. 
that is, adapted French Realism to Croatian culture. Therefore, as metaphors are sometimes used to clear the view, one can claim that in translated adaptations the periphery and the centre come closer. Or, if we go back to the enumerated hypotheses as the most concise conclusion:

1. It is important to take Šenoa's, until recently peripheral translations into account.

2. It is also necessary to take into account especially the peripheral genre of dramatic translations.

3. It is necessary to understand the translator's selections of French literature in consideration to a specific status in the historical-political relationships of European culture.

4. Those translations need to be contextualised through the selection of translations from other European languages, Czech, Hungarian, but also Polish.

5. The choice of a text for translation can actively serve to resolve the issues of aesthetics and poetics, which is one of the basic tasks of history of literature. Translation theory participates in the basic tenets of periodisation and classification in the theory of literature to that extent.

\section{Literature}

\section{Authors}

Beker M., 2001: Teorija o dinamičnom funkcionalizmu Itamara Even-Zohara. „Umjetnost riječi”, no. 1, pp. 1-12.

Bourdieu P., 1998: Les Règles de lart: genèse et structure du champ littéraire. Paris, Édition du Seuil.

Brešić V., 2015: Hrvatska književnost 19. stoljeća. Zagreb, Alfa.

Even-Zohar I., 1990: Polysystem Studies. „Poetics Today. International Journal for Theory and Analysis of Literature and Communication" 11, no. 1, pp. 1-262. Frangeš I., 1987: Povijest hrvatske književnosti. Zagreb-Ljubljana, Nakladni zavod Matice hrvatske and Cankarjeva založba.

Grgić Maroević I., 2009: Poetike prevođenja. O hrvatskim prijevodima talijanske poezije. Zagreb, Hrvatska sveučilišna naklada.

Grgić Maroević I., 2017: Politike prevođenja. O hrvatskim prijevodima talijanske proze. Zagreb: Hrvatska sveučilišna naklada.

Hanshew K., 2018: Comparing Canons: Croatian and German Realism - A Proposal. In: C. Pavlović et al., ed.: Komparativna povijest hrvatske književnosti, 
t. XX. Književni kanon. Split-Zagreb, Književi krug (Literary Circle) Department of Comparative Literature, Faculty of Humanities and Social Sciences, University of Zagreb.

Hećimović B., ed., 1990: Repertoar hrvatskih kazališta, t. 1-2, Zagreb, Globus JAZU.

Jelčić D., 1997: Povijest hrvatske književnosti. Tisućljeće od Bašćanske ploče do postmoderne. Zagreb, P.I.P. Naklada Pavičić.

Katičić R., Novak, S. P., 1987: Dva tisućljeća pismene kulture na tlu Hrvatske. Zagreb, SNL.

Lanson G., 1966: Histoire de la littérature française, remaniée et complétée par P. Tuffrau. Paris, Librairie Hachette.

Nemec K., 1994: Povijest hrvatskoga romana. Zagreb, Znanje.

Novak S. P., 2003: Povijest hrvatske književnosti. Od Bašćanske ploče do danas. Zagreb, Golden marketing.

Pavlović N., 2015: Uvod u teorije prevođenja. Zagreb, Leykam international.

Pavlović C., 2005: Priča u pjesmi. Pripovjedni postupci Šenoine epske poezije. Zagreb, Disput.

Pavlović C., 2006: Šenoina poetika prevođenja. Traduktološka analiza Šenoinih prijevoda s francuskoga jezika. Zagreb, Matica hrvatska.

Prohaska D., 1919: Pregled književnosti hrvatske i srpske I. (Do realizma 1880). Zagreb, Vlastita naklada, Kraljevska zemaljska tiskara (preštampano: Hrvatska čitanka za 3. i 4. raz., Zagreb Trgov. akademija, 1918).

Sardou V., 2012: Nos bons villageois. Pézenas, Théâtre-documentation.

Scribe E., Villeneuve T., Desvergers, 1844: Yelva, ou L'orpheline russe. Bielefeld, Velhagen \& Klasing. Online-Ausgabe: Karlsruhe: Badische Landesbibliothek. Yelva [online] https://digital.blb-karlsruhe.de/urn/urn:nbn:de:bsz:31-90123 [25.10.2018].

Šenoa A., 1963: Sabrana djela. Pjesme, t. I., ed. S. Ježić. Zagreb, Znanje.

Šenoa A., 1963: Sabrana djela. Zlatarovo zlato, t. II., ed. S. Ježić. Zagreb, Znanje.

Šicel M., 1966: Pregled novije hrvatske književnosti. Zagreb, Matica hrvatska.

Šicel M., 1997: Hrvatska književnost 19. i 20. stoljeća. Zagreb, Školska knjiga.

Ujević M., 1932: Hrvatska književnost. Pregled hrvatskih pisaca i knjiga. Zagreb, Hrvatsko književno društvo sv. Jeronima.

Živančević M., Frangeš, I., 1975: Povijest hrvatske književnosti, t. 4. Ilirizam. Realizam. Zagreb, Liber-Mladost.

\section{Translators}

Divjakinja N., trans., 2015: A. Šenoa: The Goldsmith's Treasure. Zagreb, Spiritoso. Divjakinja N., trans., 2018: A. Šenoa: The Goldsmith's Treasure. Zagreb, Spiritoso. 
Šenoa A., trans., 1870: V. Sardou: Dobričine seljaci. Igrokaz u 5 (4) činah, manuscript 449.

Šenoa A., trans., 1963: Sabrana djela. Pjesme, t. I., ed. S. Ježić. Zagreb, Znanje. Zagreb, Archives of the Division for the History of the Croatian Theater, the Institute for the History of Croatian Literature, Theater and Music at the Croatian Academy of Sciences and Arts.

\section{Cvijeta Pavlović \\ Przekład jako składnik poetyki}

STRESZCZENIE | August Šenoa należy do przejściowego okresu w literaturze chorwackiej przypadającego na czas pomiędzy romantyzmem a realizmem. Artykuł przedstawia analizę relacji między licznymi przekładami autorstwa Šenoi a jego utworami oryginalnymi wyrażającymi skłonność do estetyki realizmu, w przeciwieństwie do dominującego postrzegania poetyki Šenoi jako romantycznej. W tekście uwzględniono kulturę źródłową i docelową, kulturowe powiązania, kontakty i wymiany, a także możliwe zwroty w postrzeganiu kulturowych peryferii, jak i wpływ gospodarki na politykę kulturalną.

SŁOWA KLUCZOWE | przekład, August Šenoa, peryferie, romantyzm, realizm

\section{Cvijeta Pavlović}

\section{Translation as a Poetics Constituent}

SUMMARY | August Šenoa belongs to a transitional period of Croatian literature, falling between Romanticism and Realism. The paper analyses the relations between Šenoa's numerous translations and the poetics of his texts focusing on his proclivity towards the aesthetics of Realism, as opposed to the dominant perception of his poetics as Romanticist. This paper researches the source and target cultures, cultural links, contacts and exchanges, but also possible twists in the perception of cultural periphery, as well as the influence of economy on cultural politics.

KEYWORDS | translation, August Šenoa, periphery, romanticism, realism

CVIJETA PAVLOVIĆ | PhD, full professor (Section for Comparative Study of Croatian Literature, Department of Comparative literature, Faculty of $\mathrm{Hu}$ manities and Social Sciences, University of Zagreb). Research investigator in the research projects Comparative History of Croatian Literature (1998-2004) and European Context of Croatian Literature (2007-2012), principal investigator in the research project European Context of Croatian Literature (2013-2014), principal investigator in the research project of the University of Zagreb, Faculty 
of Humanities and Social Sciences Fantasy: A Problem of Reality (2015). A team member in the research project Dalmatia - A Destination of European Grand Tour in the 18th and 19th Century (Grand Tour Dalmatia) (HRZZ) and in the research project Economic Basis of Croatian Literature (HRZZ). She participated in the making of the Lexicon of Croatian Writers, Lexicon of World Writers, Lexicon of World Literature, Croatian Encyclopaedia, Marin Držić Lexicon, Croatian Literary Encyclopaedia, Lexicon of Literary-Cultural Terms, Lexicon of Theatre, and Antun Gustav Matoš Lexicon. She published, inter alia, the monographies entitled Poem Story - Narrative Techniques in Šenoa's Epic Poetry (2005) (Priča u pjesmi. Pripovjedni postupci Šenoine epske poezije, 2005), Šenoa's Poetics of Translation (2006) (Šenoina poetika prevođenja, 2006), Croatian and French Literary Connections. 15 Studies (2008) (Hrvatsko-francuske književne veze. 15 studija, 2008), The Introduction to the Classicism (2012) (Uvod u klasicizam, 2012); she is the editor of the scholarly series Comparative History of Croatian Literature (Komparativna povijest hrvatske književnosti, 2005-2016, 2018-2019). 